\title{
MONITORING THE PERFORMANCE OF COMMUNITY FORESTRY TO ACHIEVE REDD+ GOALS THROUGH GEOSPATIAL METHODS
}

\author{
H. Gilani ${ }^{\text {a, * }}$, Shree Krishna Gautam ${ }^{\text {b }}$ MSR. Murthy ${ }^{\text {a }}$, U. A. Koju ${ }^{a}$, K. Uddin ${ }^{a}$, B. Karky ${ }^{\text {a }}$ \\ ${ }^{a}$ International Centre for Integrated Mountain Development, Kathmandu, Nepal, Tel +977-1-5003222 Fax +977-1- \\ 5003277 (Hammad.Gilani, Upama.Koju, Manchiraju.Murthy, Kabir.Uddin, Bhaskar.Karky)@icimod.org \\ ${ }^{\mathrm{b}}$ Department of Forest Research and Survey, Nepal. Email: skgautam@dfrs.gov.np
}

KEY WORDS: MRV, REDD+, community forests, linear regress model and biomass change

\begin{abstract}
:
Measurement, reporting and verification (MRV) is included in the Cancun, Mexico, in 2010 under climate change agreements, as one of the most critical elements necessary for the successful implementation of any reducing of emissions from deforestation and forest degradation and the role of conservation, sustainable management of forests and enhancement of forest carbon stocks in developing countries (REDD+) mechanism. Community forestry is recognised as a successful model for conserving forests, raising awareness among local people and decentralising the forest governance practices. In the world, Nepal is considered as a leader in community-based forest management. This study conducted in 16 community forests ( 2384.76 ha) of Kayar Khola watershed ( 8002 ha) of Chitwan district, Nepal.

In this paper, satellite images IKONOS-2 (2002) and GeoEye-1 (2009 \& 2012) were used which have $1 \mathrm{~m}$ and $0.5 \mathrm{~m}$ ground spatial distance (GSD) respectively. Geographic information system (GIS) participatory approach was embraced for the boundaries delineation of community forests. Geographic object-based image analysis (GEOBIA) classification technique was performed and overall accuracy $94 \%$ with $92.91 \%$ producer's and $96.2 \%$ user's accuracies. Through change matrix method, 25.49 ha and 1.08 ha area deforested while 179.84 ha and 33.24 ha reforested in two time periods 2002-2009 and 2009-2012 respectively. Overall within 16 community forests, "Close broadleaved to Open broadleaved" 4.42 ha and 4 ha area is transferred between 2002-2009 and 20092012 respectively. While "Open broadleaved to Close broadleaved" 29.25 ha and 31.1 ha area is converted in seven years (20022009) and in three years (2009-2012) respectively. Coefficient of determination (R2) 0.833 achieved through a line-intercept transect between number of segmented and observed tree crowns. Maximum numbers of the counted trees exist below $20 \mathrm{~m} 2$, which show the forest of the study area is not mature and has capacity to sequestrate more and more carbon in coming years. A linear regress model obtained $\left(\mathrm{AGB}=0.0543 * \mathrm{CPA}-62.078\right.$ with $\left.\mathrm{R}^{2}=0.76\right)$ by plotting the delineated crowns from satellite image and field based biomass values at 1 ha grid. The present study was conducted in order to analyse, the performance of community forestry to achieve REDD+ goals by considering a sample of pilot project site in Nepal.
\end{abstract}

\section{INTRODUCTION}

The concept of "reducing of emissions from deforestation and forest degradation and the role of conservation, sustainable management of forests and enhancement of forest carbon stocks in developing countries" (REDD+), is agreed at the Copenhagen Conference of the Parties (COP15) to the UNFCCC (Joseph et al., 2013). In this regards, number of developing countries are carrying out pilot projects and readiness activities with financial assistance from different funding schemes of developed countries (Cerbu et al., 2011; Joseph et al., 2013; Pandey et al., 2014). Currently approximately 50 countries have initiated activities to be ready for REDD+ (Saito-Jensen et al., 2014). Measurement, reporting and verification (MRV) is included in the Cancun, Mexico, in 2010 under climate change agreements, as one of the most critical elements necessary for the successful implementation of any REDD+ mechanism. The monitoring and reporting of the present carbon resources can be achieved with many different approaches. Official guidelines for REDD + MRV are yet to be established. (Gibbs et al., 2007). IPCC (2006) described these as three Tiers, each providing more reliable data and therefore higher financial return. These three Tiers are characterized by data produced with process based models allowing transparent and accurate reporting, providing reliable and valid information updated over time and site specifications. In order to achieve Tier 3 level information, there is the need to have a robust methodology that can be replicable over the years. Remote sensing techniques in combination with ground truth data can be used to build statistical models in order to fulfil Tier $2 \& 3$ requirements (Gibbs et al., 2007).

A cost effective monitoring and evaluation system for REDD+ requires a balanced approach of remote sensing and ground measurements. New satellite remote sensing sensors are continually being launched and existing sensors are often replaced to ensure continuity in the data record. Given this enormous resource, remote sensing has proven to be an effective tool to monitor the condition of the forest. Forest cover change assessment in terms of the deforestation monitoring can rely on remote sensing technology with ground measurements for verification. While monitoring and mapping forest degradation and carbon stocks is more challenging, and largely relies on ground measurements, complemented by remote sensing (GOFC-GOLD, 2009). Several methods have been proposed for estimating forest biomass using remote sensing techniques that make use of a combination of regression models, vegetation indices, and canopy reflectance models (Kajisa et al., 2009; Gonzalez et al., 2010; Cho et al., 2012; Huang et al., 2013). In the REDD+, remote sensing based estimation, mapping and accuracy have increasing attraction for scientists (Nelson et al., 1988; Franklin and Hiernaux, 1991; Steininger, 2000; Foody et al., 2003; Lu, 2006; Zheng et al., 2008; Ahmed et al., 2013).Gibbs (2007) reviewed different remote sensing data sets by discussing the benefits, limitations and uncertainties of different remote sensing platforms.

\footnotetext{
* Corresponding author. This is useful to know for communication with the appropriate person in cases with more than one author.
} 
Over the past 30 years, most of the developing countries have transitioned toward decentralized forest management that allows local actors increased rights and responsibilities, and has helped protect forests in many regions (Agrawal and Ostrom, 2001; Agrawal and Chhatre, 2006). Community forestry is recognised as a successful model for conserving forests, raising awareness among local people and decentralising the forest governance practices (Poffenberger, 2006; Pandey et al., 2014). On a global scale, at least $10 \%$ or approximately 400 million hectares forested land management rights are with the surrounded local communities (White and Martin, 2002). Of this, more than half of the world's forests has come under their control during the past 25 years (Sunderlin, 2008). In the world, Nepal is considered as a leader in community-based forest management (Pokharel, 2012) as in the 1990s Nepal's community forestry program (CFP) gained momentum after the government made special provisions for community forests in Section 5 of the Forest Act 1993 and Section 4 of Forest Regulation 1995 (DoF, 1995; HMG, 1995; Niraula et al., 2013). The main objective of the Nepal CFP is to achieve sustainable management of forest resources by converting accessible national forests into community forests $(\mathrm{CFs})$ on a phase wise manner (DoF, 2012). The approach is very successful, not only in restoring degraded sites, biodiversity, and improving the supply of forest products to people, but also in forming local level institutions for resource management and in improving the state of the environment (Poffenberger, 2006; Niraula et al., 2013; Mbaabu et al., 2014). Now recently, Nepal has been selected as one of the four countries for promoting forest conservation by controlling deforestation and degradation as well as profiting off forest carbon stocks (Report, 2014).

Chitwan district is one of the selected 12 Tarai districts of Nepal which will benefit under the forest carbon partnership facility (FCPF) being implemented by the World Bank to utilize the carbon funds between 2015 and 2020 through the REDD+ scheme. (Report, 2014). The REDD+ pilot project from 2009 to 2013 in Nepal funded by the Norwegian development aid agency (NORAD) offered a unique and highly relevant case study since the project has the particular objective to address equity in payment distribution among the community forest user groups (CFUGs) while promoting forest carbon sequestration. The study is designed to answer a basic and key question, Are forest communities really preserving their forest on the hope to achieve REDD+ goals? The research is designed to assess, monitor and map, the performance of selected CFUGs with geospatial methods. Through geographic information system (GIS) participatory approach, already demarcated boundaries (on papers) of the community forests were made available digitally for the extraction and comparison of biophysical parameters. Kayar Khola watershed, Chitwan, Nepal, one of the REDD+ pilot sites is selected for this paper, where 16 CFUGs exist. To achieve study objectives, high resolution satellite images IKONOS-2 $(1 \mathrm{~m})$ and GeoEye-1 $(0.5$ m) images captured 2002, 2009 and 2012 were used.

\section{MATERIAL AND METHOD}

\subsection{Study Area}

The area for this study was 16 community forests, which lie in the Kayar Khola watershed located in Chitwan District, Nepal. Of the 8002 ha total area of watershed, 5821 ha area covered by forests, of which 2382.76 ha managed by 16 CFUGs composed of 23,223 people in 4163 households (Mbaabu et al., 2014). This study area lies in tropical region and tropical climate with substantial altitudinal variation, ranges from 245 to 1944 masl (see figure 1). Dominant forest tree species are hilly Shorea robusta (Sal) and Schima wallichii (Chilaune) associated with other species like Lagerstroemia parviflora (Botdhairo), Adina cordifolia (Haldu), Rhus wallichii (Kag Bhalayo), Castanopsis indica (Katus) etc. In the selected study area, forest is regenerated over the time.

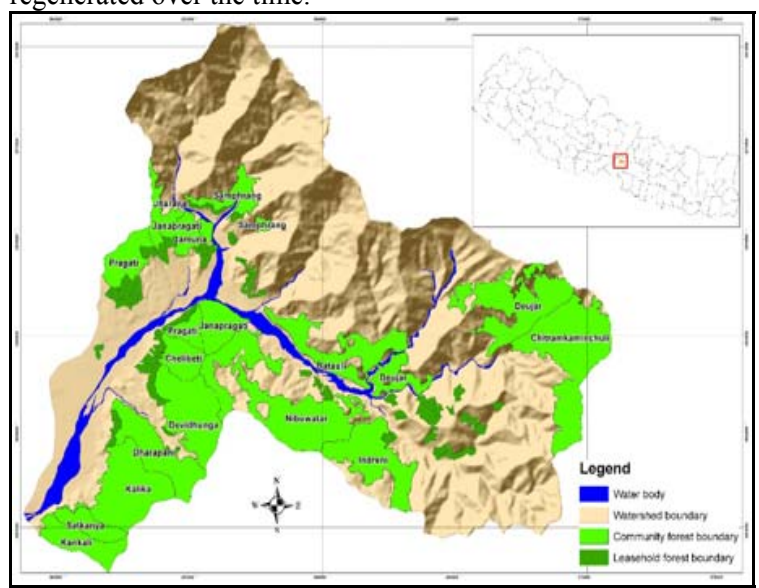

Figure 1: Study area map

\subsection{Data and software used}

In this paper, satellite images IKONOS-2 and GeoEye-1 were used which has $1 \mathrm{~m}$ and $0.5 \mathrm{~m}$ ground spatial distance (GSD) respectively. IKONOS-2 satellite images were acquired on 3rd August 2002 by IKONOS while GeoEye-1 images were acquired on 2nd November 2009 and 15th December 2012. Band by band all images were ortho-rectified using the rational polynomial coefficients (RPC) files and $20 \mathrm{~m}$ (horizontal resolution) digital elevation model (DEM) with an average accuracy of multispectral $0.7 \mathrm{~m}$ average root mean square error (RMSE) and $0.25 \mathrm{~m}$ for the panchromatic image. Intensity, hue and saturation (IHS) spatial image enhancement technique adopted using multispectral and panchromatic images of respective year's satellite data for image segmentation and classification.

In addition to remotely sensed data, total 51 forest inventory plots were collected on $500 \mathrm{~m} 2$ circular plots of radius $12.62 \mathrm{~m}$ with measurements of tree parameters i.e. $\mathrm{DBH}$, height, crown diameter, species and canopy cover. Field campaigns were carried out in different time intervals of September 2010 to December 2012. By using the plot level above ground biomass (AGB) values, regression model formation and validation was done. GIS basic layers, like administrative boundaries, roads, settlements, spot heights, contours etc. were used for the map formation.

\subsection{Delineation of community forests (CFs)}

GIS participatory approach was embraced for the boundaries delineation of community forests. Field maps were prepared using the high resolution GeoEye-1 (2009) satellite images in A0 size. Additional information like settlements, roads and contours etc. from the topographic maps were included over the prepared maps for better identification of locations in the field. Ancillary information such as the existing maps and descriptions prepared by the CFUGs were used as the basis for demarcation. Features like streams, ridges and trails were helped to identify the exact locations. In the areas where the community forests and other forests (national or leasehold) were adjacent to each other, GPS surveys were carried out along with the local participants. The demarcated areas were then plotted on the field maps which were digitized in the GIS format (i.e. polygon shape files). A workshop with CFUG members and district forest office (DFO) was conducted for 
endorsement of the digital maps. Digitally CFs boundaries were used for the extraction of biophysical attributes derived from the satellite imagery.

\subsection{Forest cover change assessment}

For the assessment, monitoring and mapping forest condition within and surrounded areas of selected 16 CFUGs over the 10 years high resolution satellite images (2002-2009-2012) geographic object-based image analysis (GEOBIA) classification technique was performed. Multi-resolution image segmentation was selected to locate objects and boundaries electronically within digital images to facilitate analysis. Segmentation parameters, scale-400, shape- 0.7 , and compactness- 0.3 were compatible for the selection of land cover classes properly. Spectral and spatial characteristics rule based image classification was performed over the segmented images. Vegetation related image indices (e.g. normalized difference vegetation index, soil-adjusted vegetation index etc.) and DEM with its products helped to define image classification rule sets. Five major land cover classes were mapped including two forest classes, close and open broadleaved forest (see the table 1). The overall accuracy of the classified 2009 image was determined with producers' and user's accuracies along the kappa value through confusion matrix error based on the 150 reference points (Foody, 2002). Land cover 2009 map was taken as a reference to classify 2002 and 2012 satellite image.

\begin{tabular}{|c|c|c|}
\hline No & Land cover classes & Description \\
\hline 1 & $\begin{array}{l}\text { Closed } \\
\text { broadleaved forest }\end{array}$ & $\begin{array}{l}\text { Land areas covered with } \\
\text { trees with }>40 \% \text { canopy } \\
\text { cover }\end{array}$ \\
\hline 2 & $\begin{array}{l}\text { Open broadleaved } \\
\text { forest }\end{array}$ & $\begin{array}{l}\text { Land areas covered with } \\
\text { trees with }<40 \% \text { canopy } \\
\text { cover }\end{array}$ \\
\hline 3 & $\begin{array}{l}\text { Agriculture and } \\
\text { built-up area }\end{array}$ & $\begin{array}{l}\text { Agriculture areas both } \\
\text { currently cultivated and } \\
\text { fellow lands associated with } \\
\text { land covered by the humans } \\
\text { for the settlements }\end{array}$ \\
\hline 4 & Barren area & $\begin{array}{l}\text { Areas with no vegetation } \\
\text { cover, uncultivated } \\
\text { agricultural lands }\end{array}$ \\
\hline 5 & Water body & $\begin{array}{l}\text { Perennial rivers and rivers } \\
\text { without water or very little } \\
\text { water }\end{array}$ \\
\hline
\end{tabular}

Table 1. Definitions of land cover classes

The forest stability and the performance of CFs over the 10 years in 8002 ha total area was monitored and mapped using the change matrix method. In the defined area "Deforestation", and "Reforestation", were extracted at two intervals 2002-2009 and 2009-2012. Land covers were extracted based on the 16 community forests boundaries.

\subsection{Tree canopy monitoring}

Degradation of forest-cover is often a complex process (Lambin, 1999) and it is of great concern to the people in the developing countries where REDD+ programmes are being implemented (Nandy et al., 2011). In this paper within the community forests, through change matrix among two forest classes close and open broadleaved forest alteration were assessed over two time periods 2002-2009 and 2009-2012.

By taking the advantage of high resolution satellite imagery, change in tree crowns number verses coverage area by different tree crowns size classes were statistically and graphically analyzed. GEOBIA's region growing technique was embarked for the detection and delineation of tree crowns from the high resolution satellite imagery. The scale- 10 , shape- 0.7 , and compactness- 0.3 used in segmentation of IKONOS-2 and GeoEye-1 images. The image segmentation parameters were chosen through the estimation of scale parameter (ESP) tool proposed by the Drăguţ et al. (2010). In region growing, tree tops are identified as maxima and the shadows between neighbouring trees as minima. The segments are 'grown' from these maxima and the valleys act as boundaries. The first step in region growing was to create minimal size homogeneous objects through so-called 'chessboard segmentation' from which the brightest pixels are identified as seed pixels (tree tops). Regions are 'grown' from the seed pixels up to the local minima, resulting in homogeneous objects based on predefined homogeneity criteria (Culvenor, 2002; Ke and Quackenbush, 2011b). Accuracy assessment of delineated tree crowns is adopted from Ke and Quackenbush (2011a) and (Culvenor, 2002), a line-intercept transect method was adopted by plotting the manually verse GEOBIA counted number of trees to know the coefficient of determination.

\subsection{Carbon sequestration - Biomass change}

In this study, at local level species wise allometric equation relating both $\mathrm{DBH}$ and height to biomass were not available hence a generalized equation recommended by Chave et al. (2005) for tropical moist hardwood forests was used. For the proposed equation, wood specific gravities were used for each tree species available through the Chaturvedi and Khanna (1982). A linear regression relationship at 1 ha grid $(100 \mathrm{~m}$ by $100 \mathrm{~m}$ ) was developed between variables 1) Biomass from field plots and 2) Crown projection area (CPA) from high resolution satellite images. The satisfactory coefficient of determination (R-squared) helped to apply the linear regression for the estimation of biomass for the entire study area. The model was calibrated and validated using 65\% (31 plots) and 35\% (20 plots) of the field data respectively. AGB was compared among the 16 CFs at three time intervals, 2002, 2009 and 2012. Based on the generated AGB, spatial change maps prepared to assess the improvement or deterioration at 1 ha grid scale.

\section{RESULTS}

\subsection{Digital database of community forests}

After the satisfaction from the CFUGs and DFO, Chitwan, in a workshop, total 16 community forests were digitally availed (see figure 1). According to digital debase, 16 CFUGs contain total 2382.76 ha. These community forests, established date were difficult to trace out but hand over data to respective user groups is available from the government (see table 2). In this area, oldest one Kankali community forest which was handed over in 1995s while mostly after the 2000's, was officially given to CFUGs.

\begin{tabular}{|l|l|l|l|}
\hline No & CF name & $\begin{array}{l}\text { Digitized area } \\
\text { (ha) }\end{array}$ & $\begin{array}{l}\text { Handed over } \\
\text { data }\end{array}$ \\
\hline 1 & Batauli & 155.77 & $31 / 10 / 2008$ \\
2 & Chitramkaminchuli & 314.02 & $22 / 03 / 2009$ \\
3 & Deujar & 278.87 & $23 / 12 / 2002$ \\
4 & Devidhunga & 191.79 & $27 / 10 / 2010$ \\
5 & Chelibeti & 64.87 & $27 / 10 / 2010$ \\
6 & Dharapani & 147.16 & $18 / 04 / 2007$ \\
7 & Indreni & 172.17 & $22 / 03 / 2009$ \\
8 & Jamuna & 34.53 & $21 / 09 / 2004$ \\
\hline
\end{tabular}




\begin{tabular}{|l|l|l|l|}
\hline 9 & Janapragati & 118.84 & $16 / 07 / 2003$ \\
10 & Jharana CF & 34.53 & \\
11 & Kalika & 213.77 & $15 / 07 / 2001$ \\
12 & Kankali & 91.60 & $19 / 09 / 1995$ \\
13 & Nibuwatar & 329.18 & $29 / 05 / 2006$ \\
14 & Pragati & 115.48 & $21 / 09 / 2004$ \\
15 & Samfrang CF & 63.90 & $23 / 09 / 2010$ \\
16 & Satkanya & 58.28 & $12 / 09 / 2004$ \\
\hline
\end{tabular}

Table 2. Delineated community forest in Kayar Khola watershed, Chitwan

\subsection{Forest cover change assessment}

Overall accuracy $94 \%$ with $92.91 \%$ producer's, $96.2 \%$ user's accuracies and 0.91 kappa value of land cover 2009 were achieved using 141 out of 150 corrected sample plots. Further land cover 2009 has been taken as a reference for the formation of land cover 2002 and 2012.

Through change matrix method, 25.49 ha and 1.08 ha area were deforested while 179.84 ha and 33.24 ha reforested in two time periods 2002-2009 and 2009-2012 respectively (see table 3 ). So in the study area, improvement in forest cover can be appraised with almost no deforestation.

\begin{tabular}{|l|l|l|}
\hline & \multicolumn{2}{|c|}{ Area (ha) } \\
& $2002-2009$ & $2009-2012$ \\
\hline Deforestation & 25.49 & 1.08 \\
Reforestation & 179.84 & 33.24 \\
\hline
\end{tabular}

Table 3. Change in land and forest cover (2002-2012)

In last 10 years, forest area increased in individual basis as well as collectively in all 16 community forests with almost no deforestation, spatial changes also captured in the form of graph and maps (see figure 2). Although, from last 3 years (20092012) the rate of forest increment is not that much as compared to initial 7 years (2002-2009).

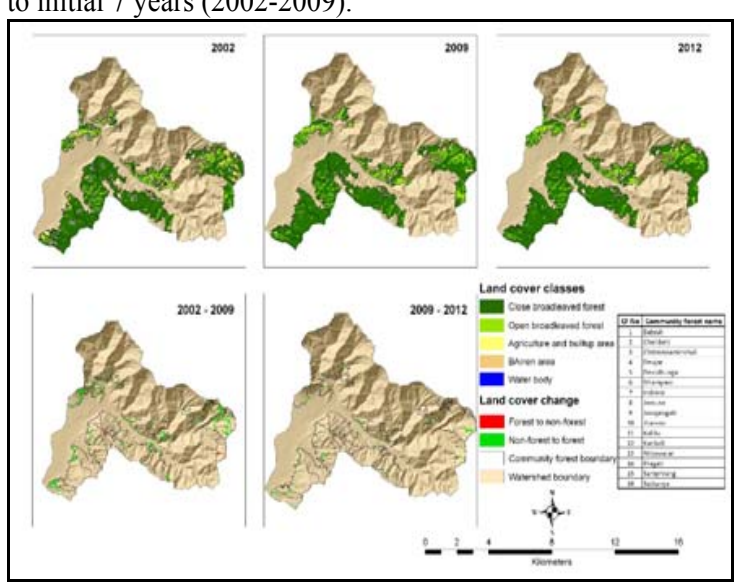

Figure 2: Land and forest cover spatial changes within community forests (2002-2012)

\subsection{Tree canopy monitoring}

Overall within 16 community forests, "Close broadleaved to Open broadleaved" (in other words, we can say forest degradation) 4.42 ha and 4 ha area is transferred between 20022009 and 2009-2012 respectively. While "Open broadleaved to Close broadleaved" (in other words, we can say forest aggradation) 29.25 ha and 31.1 ha area is converted in seven years (2002-2009) and in three years (2009-2012) respectively (see table 4).

\begin{tabular}{|l|l|l|}
\hline & \multicolumn{2}{|c|}{ Area (ha) } \\
& $2002-2009$ & $\begin{array}{l}2009- \\
2012\end{array}$ \\
\hline $\begin{array}{l}\text { Close broadleaved to Open } \\
\text { broadleaved } \\
\text { Open broadleaved to Close } \\
\text { broadleaved }\end{array}$ & 4.42 & 4.0 \\
\hline
\end{tabular}

Coefficient of determination $\left(\mathrm{R}^{2}\right) 0.833$ was achieved through a line-intercept transect between number of segmented and observed tree crowns. In each tree crown class, incremental in number of trees was observed with the transformation of crown size classes. According to the figure 3 , in each tree crown size class, either slight or substantial positive change can be detectable. Maximum number of the counted trees exist below $20 \mathrm{~m}^{2}$, which show the forest of the study area is not mature and has capacity to sequestrate more and more carbon in coming years (Hemery et al., 2005). At each community forests level, total tree crowns area over the geographic area coverage is shown in figure 4. Contrary to forest degradation, in each community forest improvement is observed.

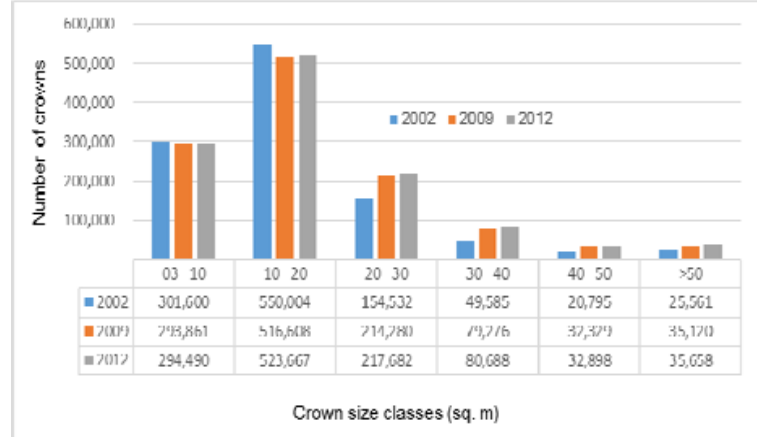

Figure 3: Change in number of tree crowns based of tree crown area sizes

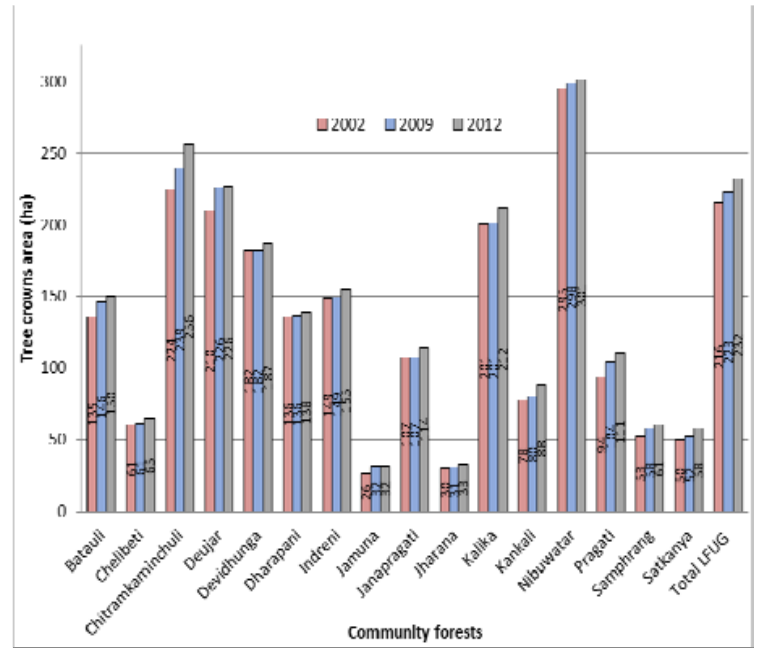

Figure 4: Tree cover area in each community forest (20022012)

\subsection{Spatially above ground biomass change}

A linear regression model obtained $\left(\mathrm{AGB}=0.0543^{*} \mathrm{CPA}\right.$ 62.078 with $\mathrm{R}^{2}=0.76$ ) by plotting the delineated crowns from satellite image and field based biomass values at 1 ha grid. In the validation of regression model $84 \%$ accuracy achieved using 20 sample plots between predicted and observed biomass values at 1ha grid. Spatial AGB between 2002 -2009 reveals 
deteriorations in most of the community forests while, in between 2009-2012,very few area are under this threat with lots of improvements (see figure 5).

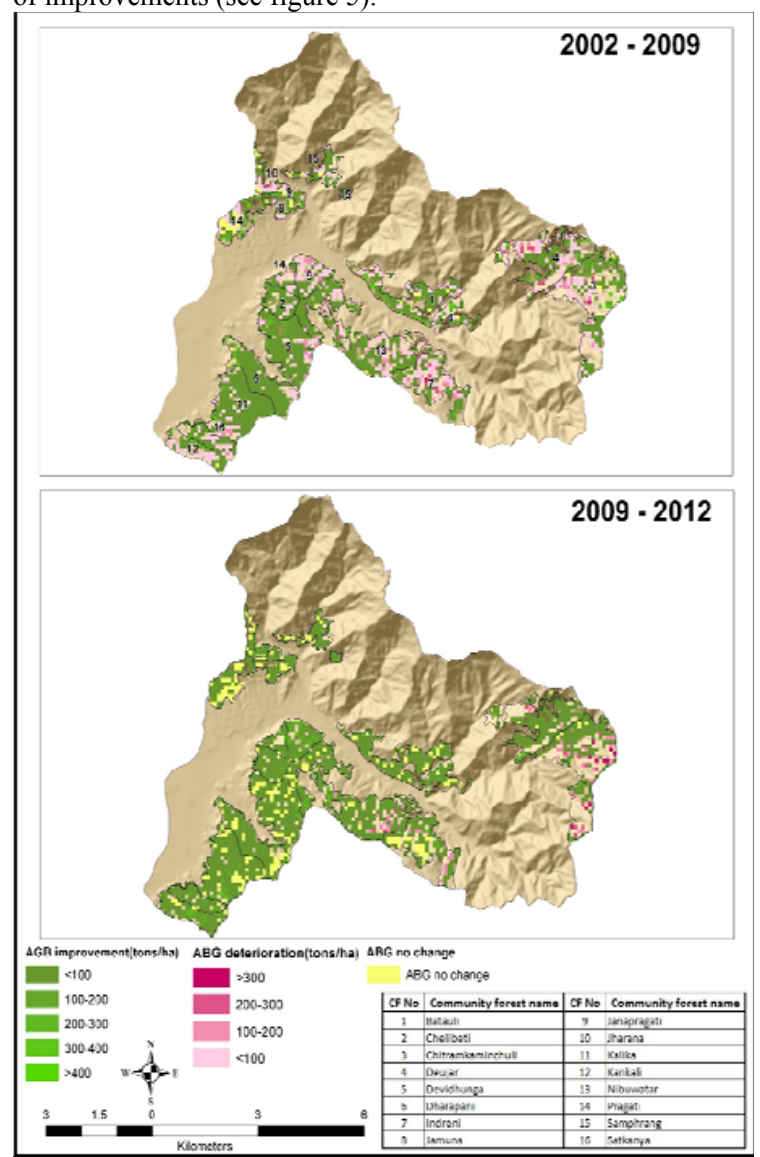

Figure 5: AGB change map (2002-2012)

\section{DISCUSSION AND CONCLUSION}

The present study was conducted in order to analyze, the performance of community forestry to achieve REDD+ goals by considering a sample of pilot project site in Nepal. This paper illustrates, a practically example of assessment, monitoring and mapping deforestation, forest degradation and AGB changes in ten years using high resolution satellite images over 16 community forests. REDD+ payment mechanism is performance- based or result-based, so in this regard MRV is essential and remote sensing methods can quantify. Practically quantification and reporting deforestation is quite easy while on the other hands forest degradation and biomass/carbon stock change are very thought provoking tasks. Lambin (1999) explained the role of remote sensing in forest degradation, the author is trying to explain how spectral, spatial and temporal information could be used to access the forest degradation. Gibbs et al. (2007) reported, overall low to medium uncertainty of very high resolution optical remote sensors with one of the major limitations i.e. "No allometric relations based on crown area are available" but now this has been overcome with the advance geospatial methods (Song and Dickinson, 2008; Mbaabu et al., 2014). Thompson et al. (2013) proposed seven indicators for the five criteria through remotely sensed (although improving calibration requires ground work) to determine forest degradation under a sustainable ecosystem management. Mbaabu et al. (2014) conducted a study in the same watershed (i.e. Kayar Khola) by opting multi-resolution segmentation for individual tree crowns generation through very high resolution (VHR) GeoEye-1 satellite image and airborne LiDAR data. They found linear regression relationship between CPA, height, and AGB resulted in accuracies of $\mathrm{R}^{2}$ range from 0.62 to 0.81 . Pandey et al. (2014) led a study in the same area based on purely community measured annually permanent

sample plots (2010-2013). They illustrated that average biomass carbon was greater in dense canopy forests than sparse ones in all vegetation types, most particularly Shorea robusta forests followed by mixed broadleaved forests, Rhododendron Quercus forests.

In this paper we have revealed in 16 digitally delineated community forests, no deforestation, almost no forest degradation and improvement of AGB in last 10 years. We used a consistent methodology using potentially available high resolution satellite images (see table $3 \& 4$, Figure 5). FerrettiGallon and Busch (2014), through meta-analysis, systematically reviewed 117 spatially explicit econometric studies of drivers of deforestation published in peer-reviewed academic journals from 1996-2013. They found a very strong linkage between indigenous peoples and community forestry with less deforestation. In Nepal to date, 17,685 CFUGs and 6934 LHFs groups have been formed (DoF, 2012). In Nepal, the community involvement has the potential to improve effectiveness, efficiency and equity (3Es) from REDD+ projects but it is also fact that, CFUGs cannot solve all the problems of forest governess (Agrawal and Ostrom, 2001; Ridish, 2008; Dhital, 2009; Bhattarai, 2012).

Forest mensuration (deforestation, forest degradation and biomass/carbon stocks changes) through high resolution satellite images provide transparent results but systematic and non-systematic satellite sensors distortion need to tackle for accurate assessments and monitoring (Sertel et al., 2007). The study area lies in the foot hills, tree canopies hidden in the shadowed areas were detected and delineated by manually and applying the edge detection algorithm. Ozdemir (2008) adopted same procedure for the estimation of stem volume of open Crimean juniper forests using Quickbird imagery in tree shadow area. In this study, another snag was faced, that was computing of outsized pan-sharpened high resolution satellite imagery. For time saving and fast output products batch, processes through supercomputing technology need to implement on regular basis (Menemenlis et al., 2005). GeoEye1 and IKONOS-2 comprises only four spectral bands, which is difficult in separability of available tree species for biomass. In recent years WorldView-2 provides hyper-spectral very high resolution $(0.5 \mathrm{~m})$ satellite imagery for the estimation of biomass at species level (Eckert, 2012; Latif et al., 2012; Mutanga et al., 2012).

Micro level studies and visual interpretations revealed that Nepal's forest coverage and condition is significantly improving due to the community forestry intervention (Dongol, 2002 ; Bhattarai, 2008; Niraula et al., 2013) No doubt, Nepal is progressing in terms of preservation of forest and improvement of livelihood of local communities but still institutional step-ups are not fully functional to provide the incentive. Through this study we have observed and mapped enhancement in forest carbon, so performance based payment mechanism works very well. Overall in Nepal land/forest degradation factors (i.e. poor soil management practice, unmanaged mining activities, forest fires, shifting cultivation etc.) are subsequently reduced through awareness and lesson learnt (Upadhyay et al., 2005).

Through this paper we can conclude that the community forestry in Nepal is playing major contribution in forest biomass/carbon enhancement. Remote sensing methods have proven its importance in the pre and post forest mensuration in implementation of REDD+ MRV. Now watershed to landscape 
level biomass up-scaling techniques need to be explored and should be well placed in cost effective manner. Now taking the current forest stock, international communities/donors need to invest the resources in providing the alternative energy and credit for long time sustainability.

\section{ACKNOWLEDGEMENT}

First of all we would like to express our deep thanks to the donor agencies "NORAD and SERVIR-NASA, USAID" and implementing agencies "ANSAB, FECOFUN and ITCNetherlands". We express our gratitude to the district' DFOs, and forest department staff. Without active participation of CFUGs this work was not possible, so we are very much thankful to them. We are very much thankful to our former colleagues Mr. Salman Asif Siddique and Eak Bahadur Rana for helping at the initial phase of this project. The findings reporte stand as scientific study and observations of the authors and do not necessarily reflect as the views of author's institute.

\section{REFERENCES}

Acharya, K.P., 2002. Twenty-four years of community forestry in Nepal. International Forestry Review 4, 149-156.

Balderas Torres, A., Lovett, J.C., 2012. Using basal area to estimate aboveground carbon stocks in forests: La Primavera Biosphere's Reserve, Mexico. Forestry.

Cho, M.A., Mathieu, R., Asner, G.P., Naidoo, L., van Aardt, J., Ramoelo, A., Debba, P., Wessels, K., Main, R., Smit, I.P.J., Erasmus, B., 2012. Mapping tree species composition in South African savannas using an integrated airborne spectral and LiDAR system. Remote Sensing of Environment 125, 214-226.

Cui, W., Guan, Z., \& Zhang, Z. , 2008. An improved region growing algorithm for image segmentation, International Conference on Computer Science and Software Engineering. DeFries, R., Achard, F., Brown, S., Herold, M., Murdiyarso, D., Schlamadinger, B., de Souza, C., 2007. Earth observations for estimating greenhouse gas emissions from deforestation in developing countries. Environmental Science \& Policy 10, 385394.

DoF, 2012. Department of Forest, Government of Nepal. (Retrieved from http://www.dof.gov.np/ on 28 January, 2013).

Erikson, M., 2003. Segmentation of individual tree crowns in colour aerial photographs using region growing supported by fuzzy rules. Canadian Journal of Forest Research 33, 15571563.

Erikson, M., \& Olofsson, K. , 2005. Comparison of three individual tree crown detection methods. Machine Vision and Applications 16, 258-265.

FAO, 2010. Global forest resources assessment 2010 country report: Nepal, Rome.

Gibbs, H.K., Brown, S., Niles, J.O., Foley, J.A., 2007. Monitoring and estimating tropical forest carbon stocks: making REDD a reality. Environmental Research Letters 2, 045023.

Goetz, S.J., Baccini, A., Laporte, N.T., Johns, T., Walker, W., Kellndorfer, J., Houghton, R.A., Sun, M., 2009. Mapping and monitoring carbon stocks with satellite observations: a comparison of methods. Carbon Balance Manag 4, 2.

Gonzalez, P., Asner, G.P., Battles, J.J., Lefsky, M.A., Waring, K.M., Palace, M., 2010. Forest carbon densities and uncertainties from Lidar, QuickBird, and field measurements in California. Remote Sensing of Environment 114, 1561-1575.

Huang, W., Sun, G., Dubayah, R., Cook, B., Montesano, P., Ni, W., Zhang, Z., 2013. Mapping biomass change after forest disturbance: Applying LiDAR footprint-derived models at key map scales. Remote Sensing of Environment 134, 319-332.

Kajisa, T., Murakami, T., Mizoue, N., Top, N., Yoshida, S., 2009. Object-based forest biomass estimation using Landsat
ETM plus in Kampong Thom Province, Cambodia. Journal of Forest Research 14, 203-211.

Ke, Y., \& Quackenbush, L. , 2008. Comparison of individual tree crown detection and delineation methods, ASPRS Annual conference "Bridging the Horizons: New Frontiers in Geospatial Collaboration.

Kim, S.R., Kwak, D.A., Lee, W.K., Son, Y., Bae, S.W., Kim, C., Yoo, S., 2010. Estimation of carbon storage based on individual tree detection in Pinus densiflora stands using a fusion of aerial photography and LiDAR data. Sci China Life Sci 53, 885-897.

Kwak, D.-A., Lee, W.-K., Lee, J.-H., Biging, G.S., Gong, P., 2007. Detection of individual trees and estimation of tree height using LiDAR data. Journal of Forest Research 12, 425-434.

Lovell, J.L., and Graetz, R.D., 2001. Filtering pathfinder AVHRR land NDVI data for Australia. International Journal of Remote Sensing 22, 2649-2654.

$\mathrm{Lu}, \mathrm{D}$., 2006. The potential and challenge of remote sensing based biomass estimation. International Journal of Remote Sensing 27, 1297-1328.

Muukkonen, P., Heiskanen, J., 2007. Biomass estimation over a large area based on standwise forest inventory data and ASTER and MODIS satellite data: A possibility to verify carbon inventories. Remote Sensing of Environment 107, 617-624.

Niraula, R.R., Gilani, H., Pokharel, B.K., Qamer, F.M., 2013. Measuring impacts of community forestry program through repeat photography and satellite remote sensing in the Dolakha district of Nepal. Journal of Environmental Management 126, 20-29.

Platt, R.V., Schoennagel, T., 2009. An object-oriented approach to assessing changes in tree cover in the Colorado Front Range 1938-1999. Forest Ecology and Management 258, 1342-1349.

Shih, F.Y., Cheng, S., 2005. Automatic seeded region growing for color image segmentation. Image and Vision Computing 23, 877-886.

Singh, B.K., Chapagain, D.P., 2006. Trends in forest ownership, forest resources tenure and institutional arrangements: are they contributing to better forest management and poverty reduction?, Understanding forest tenure in South and Southeast Asia. Forestry Policy and Institutions Working Paper 14, FAO, Rome., pp. 115-151

Yang, X., Strahler, A.H., Schaaf, C.B., Jupp, D.L.B., Yao, T., Zhao, F., Wang, Z., Culvenor, D.S., Newnham, G.J., Lovell, J.L., Dubayah, R.O., Woodcock, C.E., Ni-Meister, W., 2013. Three-dimensional forest reconstruction and structural parameter retrievals using a terrestrial full-waveform lidar instrument (Echidna $\left.{ }^{\circledR}\right)$. Remote Sensing of Environment 135, $36-51$. 